\title{
O eternamente novo no mesmo Evangelho Implicações teológico-pastorais para a evangelização das tribos urbanas de rosto underground
}

\author{
Orientador: Joel Portella Amado \\ Doutorando: Julio Cezar de Paula Brotto \\ Área de Concentração: Teologia Sistemático-Pastoral \\ Linha de Pesquisa: Religião e Modernidade
}

Neste momento que a humanidade atravessa uma mudança de época, diagnosticada de formas diferentes e até antagônicas, com diferentes cosmovisões que advogam sua verdade muitas vezes de forma absoluta, não raras vezes fundamentalista, as Igrejas Cristãs precisam responder ao desafio de falar de Deus para o ser humano que vive em contexto urbano. A Pastoral Urbana é desafiadora na medida em que os agentes pastorais enfrentam uma diversidade cultural aguda. O confuso processo de globalização que procura produzir uma sociedade culturalmente homogênea, contraditoriamente tem produzido identidades múltiplas, com matrizes multiculturais. O horizonte cultural dos receptores da Palavra de Deus em ambiente urbano é cada vez mais complexo, afetado por um multiculturalismo agudo. Neste contexto urbano os agentes pastorais defrontam-se na contemporaneidade com pessoas vinculadas às tribos urbanas de rosto underground. $\mathrm{O}$ horizonte cultural destes receptores é a cultura underground. Anunciar a Boa Nova de Jesus Cristo para essas pessoas vinculadas às tribos urbanas de rosto underground implica que os agentes evangelizadores saibam distinguir claramente entre Fé e Cultura buscando discernir entre o que efetivamente pertence ao núcleo da Revelação e o que é marca histórico cultural. Sendo assim a questão de fundo desta tese está relacionada à sua proposta de construção de uma matriz evangelizadora de linha inculturada e a partir da mesma a construção de um projeto evangelístico-missionário para que as Igrejas Cristãs apresentem a Boa Nova de Jesus para a Cultura Underground. É fundamental que as Igrejas Cristãs abandonem a matriz evangelizadora de dominação e exclusão construída ao longo da his- 
tória do Cristianismo. A organização da tese estruturou-se a partir de três capítulos. O primeiro capítulo, que corresponde ao enfoque sociocultural, propõe uma análise dos referenciais socioculturais com o auxílio multidisciplinar das Ciências Sociais. O segundo capítulo, correspondente ao enfoque teológico, analisa os referenciais teológicos em busca de uma elaboração dos conceitos de evangelização, missão e inculturação voltados para a construção de uma matriz evangelizadora inculturada. O terceiro capítulo refere-se ao enfoque pastoral. Propõe um projeto evangelístico-missionário junto às tribos urbanas de rosto underground.

Palavras-chave: Pastoral Urbana. Tribos Urbanas. Cultura Underground. 